\title{
POTRET KECERDASAN EMOSIONAL MAHASISWA PADA PERKULIAHAN SEMINAR PENDIDIKAN JASMANI
}

\author{
Jacob Jackson Shealelo Antunes Luan ${ }^{\text {1) }}$ dan Jusuf Blegur ${ }^{2)}$ \\ ${ }^{1,2}$ Program Studi Pendidikan Jasmani, Kesehatan, dan Rekreasi, \\ Fakultas Keguruan dan Ilmu Pendidikan, Universitas Kristen Artha Wacana \\ ${ }^{1,2} \mathrm{Jl}$. Adisucipto 147, Oesapa, Kupang, 85000 \\ E-mail: jacobjacksonluan@gmail.com ${ }^{1}$, jusufblegur@ukaw.ac.id ${ }^{2)}$
}

\begin{abstract}
ABSTRAK
Umumnya masyarakat beranggapan bahwa IQ merupakan suatu kecerdasan yang paling penting dan selalu menjadi tolak ukur dalam kecerdasan seorang individu dalam meraih keberhasilan pembelajaran. Namun kecerdasan intelektual (IQ) bukanlah satu-satunya faktor yang menentukan hasil belajar mahasiswa, tetapi terdapat faktor lain yang bahkan paling dominan menentukan keberhasilan yaitu kecerdasan emosional (EQ). Tujuan penelitian ini adalah untuk menilai kecerdasan emosional mahasiswa. Responden yang terlibat adalah mahasiwa PJKR semester VI tahun akademik 2017/2018 yang berjumlah 62 orang. Data dikumpulkan menggunakan TEIQue-ASF (Trait Emotional Intelligence QuestionnareAdoloscence Short Form) yang dikembangkan oleh Petrides, Sangereau, Furnham, dan Frederikson pada tahun 2006. Hasil penelitian menunjukkan responden yang memiliki tingkat kecerdasan emosional yang sangat baik berjumlah 3 orang $(4,8 \%)$, baik berjumlah 58 orang $(93,3 \%)$,cukup berjumlah 1 orang $(1,6 \%)$. Sedangkan tidak ada responden yang memiliki kecerdasan emosional pada golongan kurang dan buruk (0\%). Dengan demikian kecerdasan emosional mahasiswa tergolong baik.
\end{abstract}

Kata Kunci: Kecerdasan Emosional, Emotional Intelligence, Kematangan Emosional, Seminar, Pendidikan Jasmani

\section{PENDAHULUAN}

Pendidikan merupakan suatu bentuk kegiatan yang dijalankan secara sistematis dengan sengaja, teratur serta berencana dengan maksud mengubah atau mengembangkan perilaku individu sesuai dengan yang diinginkan (Thaib, 2013). Mata kuliah/pembelajaran merupakan salah satu bagian integritas dalam pendidikan itu sendiri yang menyediakan proses pembelajaran sekaligus adegan pembelajaran yang memungkinkan siswa dapat belajar dengan baik. Dengan belajar diharapkan adanya suatu perubahan tingkah laku dari mahasiswa sebagai sebuah kesatuan hasil belajar. Pembelajaran harus mampu mendorong motivasi mahasiswa untuk memperoleh pengetahuan dan pengembangan wawasan serta adanya perubahan perilaku bagi setiap individu dalam ranah pendidikan secara komprehensif.

Setiap mahasiswa memiliki kepribadian dengan karakteristik yang berbeda dan sapat dipengaruhi oleh lingkungan dimana dirinya berinteraksi. Baik buruknya pengaruh dari lingkungan tersebut tergantung dari sifatsifat yang ada pada lingkungan. Mudah dan tidaknya mahasiswa terpengaruhi, sangat bergantung pada kondisi psikologis (kematangan mentalnya) untuk menerima intervensi lingkungan tempat ia berinteraksi sosial. Namun demikian, umumnya individu yang memiliki psikologi mental lemah dan labil lebih mudah terkontaminasi dan terbawa energi negatif dari lingkungannya dibandingkan dengan bermental kuat atau stabil (Blegur \& Wasak, 2017).
Kesuksesan mahasiswa dalam proses pembelajaran bukan hanya ditentukan oleh faktor kognitif dan psikomotor saja, tetapi faktor psikologis berkaitan dengan kecerdasan emosional juga sangat mempengaruhi performa dan hasil belajar mahasiswa. Ada sejumlah mahasiswa yang mengalami hambatan dalam pembelajaran. Acapkali menggangu dan menggoncang proses belajarnya yang dimotoris oleh faktor psikologis, sehingga pada kenyataannya dalam proses belajar mengajar sering dijumpai mahasiswa tidak dapat meraih hasil belajar dan prestasi yang setara dengan kemampuan inteligensinya. Sebaliknya ada mahasiswa yang kemampuan inteligensinya rendah, dapat meraih prestasi atau hasil belajar yang tinggi. Itu sebabnya, taraf inteligensi bukan satu-satunya faktor yang menentukan keberhasilan seseorang (Gusniwati, 2015).

Kecerdasan emosional mencakup kemampuan yang berbeda dan saling melengkapi dan berkolaborasi dengan kemampun kognitif yang disebut dengan kecerdasan intelektual rasional (IQ). Meskipun mahasiswa memiliki IQ yang tinggi, tetapi EQ rendah biasanya tidak banyak membantu mereka dalam segala aspek kehidupannya (Daud, 2012). Kondisi tersebut selaras dengan hasil penelitian yang dilakukan oleh Nwadinigwe \& Obieke (2012). Temuan mereka menunjukkan bahwa ada hubungan signifikan yang relevan dan positif antara kecerdasan emosional dengan prestasi akademik. Sehingga perkembangan kecerdasan emosional akan mengembangkan dan meningkatkan prestasi akademik mahasiswa. Sehingga apabila mahasiswa telah memiliki kecerdasan emosional yang bagus, maka ia dipastikan 
memiliki hasil belajar yang baik, tetapi tidak berlaku umum untuk sebaliknya.

Keterampilan dan kecakapan yang dipelajari dalam paktivitas pembelajaran juga bukan hanya ketrampilan gerak atau fisik semata, akan tetapi terkait pula dengan keterampilan sosial, seperti kesadaran diri, pengaturan diri, motivasi yang tinggi, menahan sabar, berempati kepada orang lain, kepercayaan diri, emosi tidak stabil dan masih banyak lagi. Kecerdasan emosional membantu mahasiswa mengatasi masalah dengan kerugian sekecil mungkin. Pembelajaran harus mampu menyediakan pengalaman faktual untuk membina dan mengembangkan kemampuan tersebut. Apalagi proses pembelajarannya dirancang sebaik mungkin secara sistematis dan juga dijadikan sebagai adegan untuk melatih kecerdesan emosional mahasiswa. Tak pelak ini juga merupakan cara pembinaan moral yang efektif (Husdarta, 2015).

Rumusan kecerdasan emosional pernah dikelomppokkan oleh Daniel Goleman menjadi lima aspek fundamnetal, meliputi: 1) Kesadaran diri, 2) pengaturan diri, 3) Motivasi, 4) Empati, dan 5) Keterampilan sosial (Sumiyarsih, Mujiasih, \& Ariati, 2012). Faktor keberhasilan mahasiswa dalam belajar ternyata bukan hanya ditentukan oleh faktor pendidikan formal. Bahkan juga bukan hanya ditentukan oleh kecakapan kecerdasan intelektual tetapi kontribusi terbesar yang mendukung keberhasilan seseorang adalah kecerdasan emosionalnya.

Ada hal yang menarik dalam laporan penelitian Daniel Goleman. Goleman menjelaskan bahwa orang ber-IQ rendah lebih sukses dalam hidupan ketimbang orang dengan IQ tinggi. Perbedaan utama yang menyebabkan kesuksesannya ialah pada kecerdasan emosional, yang termasuk pengendalian diri, semangat, dan ketekunan, serta kemampuan uintuk memotivasi diri sendiri. Mahasiswa yang cerdas emosionalnya mampu untuk memahami persaannya dirinya sendiri dan perasaan orang lain. Karena pengenalan perasaan diri yang baik, mereka mampu memotivasi dirinya sendiri serta mampu menata dengan baik emosi-emosi yang muncul dalam dirinya dan dalam beriteraksi dengan orang lain atau lingkungannya sekitar (Gitosarono, 2012).

Hal positif akan diperoleh bila mahasiswa yang mempelajari kecerdasan emosional. Secara emosional mereka lebih pandai dalam mengendalikan perilaku mereka. Mereka tidak akan agresif menyikapi berbagai persoalan problematik (Guswani, 2011). Mereka juga selalu memiliki kondisi perasaan atau reaksi perasaan yang stabil terhadap suatu obyek permasalahan. Sehingga untuk mengambil suatu keputusan atau bertingkah laku didasari dengan suatu pertimbangan dan tidak mudah berubah-ubah dari suatu uasana hati ke suasana hati lainnya (Fatchurahman \& Pratikto, 2012). Mereka lebih penuh pengertian, mudah menerima perasaan-perasaan, dan lebih banyak pengalaman dalam memecahkan permasalahannya sendiri. Bahkan perilaku- perilaku yang desktruktif yang muncul disekitar mereka mampu direduksi dengan baik.

Mengajar pada mahasiswa dengan motivasi belajar yang tinggi amatlah penting karena mereka terpacu untuk belajar dengan aktif dan ini ada pada pribadi dengan kecerdasan emosional yang tinggi (Rahman, Sulistiawaati, \& Arifin, 2018). Motivasi dan semangat sangat membantu mahasiswa dalam melakukan perubahan ke arah yang lebih positif dari sebelumnya. Selain itu, mereka juga bersikap lebih optimis dalam tekanan serta penyelesaian masalah yang dihadapi (Setyowati, Hartati, \& Sawitri, 2010). Mereka juga dengan mudah berinteraksi secara sosial dengan teman sekitar, baik interaksi fisik maupun interaksi verbal (Putri, Asrori, \& Astuti, 2015) sehingga memudahkan mereka untuk diterima di berbagai kalangan karena pandai dalam mengelola diri.

Kecerdasan emosional adalah konstruk dinamis yang dipengaruhi oleh beragam faktor biologis, psikologis, dan sosial. Sejumlah penelitian telah dilakukan pada kecerdasan emosional dan ditemukan muncul sebagai faktor penting dalam prediksi kesuksesan pribadi, akademik dan karir (Labhane \& Baviskar, 2015). Misalnya individu yang memiliki kercerdasan emosional tinggi, memiliki prestasi belajar yang tinggi pula (Andriani, 2014; Eva \& Kusrini, 2015), kinerja kerja (Yakub, Gunawan, \& Halim, 2015). Lebih lanjut dalam penelitian empiris lainnya, kecerdasan emosional memberi kebermanfaatan bagi kehidupan individu dengan meningkatkan motivasi berprestasi (Magnano, Craparo, Paolillo, 2016) serta memiliki perilaku yang pemaaf (Paramitasari \& Alfian, 2012).

Untuk memotret kecerdasan emosional sesorang, cukup melihat kesan yang diberikan individu tentang dirinya sendiri. Apakah individu mampu mengungkapkan dengan baik emosinya sendiri, berusaha menyetarakan diri dengan lingkungan, dapat mengendalikan perasaan, serta mampu mengungkapkan reaksi emosi sesuai dengan waktu dan kondisi yang ada sehingga interaksi dengan orang lain dapat terjalin dengan lancar dan efektif (Wulandari, 2012). Kecerdasan emosional juga dapat dipotret dari kapasitas individu untuk mengendalikan emosi (parasaan marah). Artinya, mahasiswa dapat menangkal perilaku marahnya apabila Ia cerdas dalam mengelola emosi (Paramitasari \& Alfian, 2012). Serta yang tidak kalah penting ialah, kecerdasan emosi nyatanya mampu membantu mahasiswa menemukan solusi dalam setiap masalah yang ia jumpai (Goleman dalam Ely, 2016).

Pada tahun 2009, Hamalik merumuskan bahwa mahasiswa dapat memperoleh banyak pengalaman belajar dengan cara keterlibatan secara aktif dalam pembelajaran, dibandingkan dengan mahasiswa yang hanya melihat materi atau konsep. Kadar keaktifan mahasiswa tidak ditentukan oleh aktivitas fisik semata, tetapi juga oleh mental, pengetahuan, dan emosional (Widodo \& Widayanti, 2013), misalnya melatih konsekuensi logis, memberi tanggung jawab yang 
menantang, menyiapkan berbagai metode belajar yang ekspresif, lakukan umpan balik berbasis solusi, mengevaliasi hasil belajar secara langsung, objektif, dan transparan, serta mengintegrasikan pikiran dan perilaku yang memotivasi (Blegur, Wasak, \& Pabala, 2018). Dengan demikian, pembelajaran yang dilangsungkan oleh dosen dapat menginternalisasi berbagai atribut emosional dan kognitif guna melengkapi totalitas hasil belajar mahasiswa.

\section{RUANG LINGKUP}

Kecerdasan emosional amatlah penting bagi mahasiswa, karena membantu mahasiswa menstabilisasi suasana hati dan keadaan mentalnya untuk produktif dalam kegiatan belajar melalui upaya-upayanya yang nyata. Sebab orang tidak mungkin pintar dan berhasil apabila tidak memiliki semangat dalam belajar, rasa ingin tahu yang tinggi, selalu ingin mencoba, ingin berkembang maju, konsisten dalam belajar, dan lainnya.

Kecerdasan emosional perlu dilatih untuk memperlengkapi dan meningkatkan kecerdasan intelegensi mahasiswa. Apalagi dalam era disrupsi seperti sekarang ini, kecerdasan emosional bahkan memiliki andil yang sangat krusial dalam keberhasilan seseorang dan keberhasilan organisasi. Untuk itulah sejumlah organisasi-organisasi terkemuka lebih mengunggulkan individu yang mampu bekerjsama, mampu berkomunikasi, mampu berinovasi, memiliki integritas yang tinggi, disiplin dalam bekerja, maupun bertanggung jawab atas pekerjaan.

Hasil penelitian ini akan membantu dosen untuk memotret kecerdasan mahasiswa dalam mengikuti pembelajaran. Hasil pemotretan ini selanjutnya dapat dijadikan asas dalam mengemas pembelajaran yang lebih komprehensif dalam mengukur, menilai, serta megevaluasi perilaku belajar mahasiswa. Agar kelak kecerdasan emosional juga perlu dilatih dan dibina oleh dosen ketika melangsungkan kegiatan pembelajarannya.

\section{BAHAN DAN METODE}

Penelitian ini merupakan penelitian deskriptif kuantitatif, sehingga variabel penelitian (kecerdasan emosional) hanya akan diferekuensikan dan diinterpretasi untuk menilai kecerdasan emosional responden tanpa harus melakukan pengujian hipotesis. Responden adalah mahasiswa semester VII kelas E/F di Program Studi Pendidikan Jasmani Kesehatan dan Rekreasi, Fakultas Keguruan dan Ilmu Pendidikan, Universitas Kristen Artha Wacana Kupang tahun akademik 2017/2018 sebanyak 62 orang.

Peneliti mengumpulkan data kecerdasan emosional menggunakan TEIQue-ASF (Trait Emotional Intelligence Questionnare-Adoloscence Short Form) yang dikembangkan oleh Petrides, Sangereau, Furnham, \& Frederikson pada tahun 2006. Kuesioner ini melibatkan 30 pertanyaan tertutup. Dari ke-30 pernyataan ini terdapat 15 pertanyaan positif dan 15 pertanyaan negatif $(2,4,5,7,8,10,12,13,14,16,18$,
$22,25,26$, dan 28). Responden akan menanggapi pada 5 titik skala Likert. Hasil penelitian dianalisis menggunakan analisis deskriptif kuantitatif lalu mengkategorisasi kecerdasan emosional responden menjadi lima tingkatan (lihat tabel 1).

Tabel 1. Kategorisasi Kecerdasan Emosional Responden

\begin{tabular}{|c|c|}
\hline Nilai & Kategori \\
\hline $127-150$ & Sangat baik \\
\hline $103-126$ & Baik \\
\hline $79-102$ & Cukup \\
\hline $25-78$ & Kurang \\
\hline $30-54$ & Buruk \\
\hline
\end{tabular}

\section{PEMBAHASAN}

Dari 30 pernyataan yang ditanggapi responden, 27 diantaranya memberikan jaminan pada derajat persentase kecerdasan emosional yang cukup baik, baik, dan sangat baik (nomor: 1, 2, 3, 4, 5, 6, 7, 8, 9, 10, 11, 12, 13, 14, $15,16,17,18,19,20,21,23,24,26,27,29,30$ ). Sedangkan 3 diantaranya, yaitu nomor 22, 25, dan 28 masih memberikan jaminan derajar persentase kecerdasan emosional yang kurang baik. Secara umum kecerdasan emosional merujuk pada suatu pola pemikiran, perasaan dan perilaku dalam bertindak dari masing-masing individu yang muncul dalam implementasi yang berbeda.

Kecerdasan emosional mencakup 30 pernyataan tertutup yang dianalisis menggunakan statistik deskriptif. Analisis ini sebagai teknik untuk mendeskripsikan frekuensi dan persentase setiap pernyataan sebagai representasi perasaan responden berkaitan dengan kecerdasan emosionalnya. Responden memberikan tanggapan yang menunjukan frekuensi dan persentase jumlah keseluruhan jawaban responden terhahap 30 variabel dalam kuesioner penelitian yang ditunjukan pada tabel 2 .

Tabel 2. Deskripsi Kecerdasan Emosional Responden

\begin{tabular}{|l|c|c|c|c|c|}
\hline \multirow{2}{*}{\multicolumn{1}{|c|}{ Penyataan }} & \multicolumn{5}{c|}{ Tanggapan } \\
\cline { 2 - 6 } & TS & KS & CS & S & SS \\
\hline $\begin{array}{l}\text { Mudah bagiku untuk } \\
\text { membicarakan perasaanku } \\
\text { dengan orang lain. }\end{array}$ & 0 & 0 & 21 & 28 & 13 \\
\hline $\begin{array}{l}\text { Saya sering merasa sulit } \\
\text { untuk melihat sesuatu dari } \\
\text { sudut pandang orang lain. }\end{array}$ & 0 & 0 & 33.9 & 45.2 & 21.0 \\
\hline $\begin{array}{l}\text { Saya orang yang sangat } \\
\text { termotivasi. }\end{array}$ & 0 & 12.9 & 53.2 & 32.3 & 1.6 \\
\hline $\begin{array}{l}\text { Saya merasa sulit } \\
\text { mengendalikan perasaan }\end{array}$ & 4 & 2 & 31 & 19 & 6 \\
saya. & 6.5 & 3.2 & 50.0 & 30.6 & 9.7 \\
\hline $\begin{array}{l}\text { Hidupku tidak } \\
\text { menyenangkan. }\end{array}$ & 2 & 3 & 18 & 22 & 17 \\
\hline $\begin{array}{l}\text { Saya pandai bergaul dengan } \\
\text { teman sekelas saya. }\end{array}$ & 0 & 1 & 9 & 23 & 12 \\
\hline Saya sering berubah pikiran. & 6 & 17 & 23 & 13 & 3 \\
& 9.7 & 27.4 & 37.1 & 21.0 & 4.8 \\
\hline Saya merasa sulit untuk & 3 & 3 & 25 & 21 & 9 \\
\hline
\end{tabular}




\begin{tabular}{|c|c|c|c|c|c|}
\hline $\begin{array}{l}\text { mengetahui dengan pasti } \\
\text { emosi apa yang saya } \\
\text { rasakan. }\end{array}$ & 4.8 & 4.8 & 40.3 & 33.9 & 14.5 \\
\hline $\begin{array}{l}\text { Saya merasa nyaman dengan } \\
\text { penampilan saya. }\end{array}$ & $\begin{array}{l}0 \\
0\end{array}$ & $\begin{array}{l}0 \\
0\end{array}$ & $\begin{array}{c}12 \\
19.4 \\
\end{array}$ & $\begin{array}{c}20 \\
32.3\end{array}$ & $\begin{array}{c}30 \\
48.4\end{array}$ \\
\hline $\begin{array}{l}\text { Saya merasa sulit untuk } \\
\text { membela hak saya. }\end{array}$ & $\begin{array}{c}2 \\
3.2\end{array}$ & \begin{tabular}{|c|}
9 \\
14.5 \\
\end{tabular} & \begin{tabular}{|c|}
29 \\
46.8 \\
\end{tabular} & $\begin{array}{c}16 \\
25.8\end{array}$ & $\begin{array}{c}6 \\
9.7\end{array}$ \\
\hline $\begin{array}{l}\text { Saya bisa membuat orang } \\
\text { lain merasa lebih baik saat } \\
\text { saya mau. }\end{array}$ & $\begin{array}{l}0 \\
0\end{array}$ & $\begin{array}{l}0 \\
0\end{array}$ & $\begin{array}{c}17 \\
27.4\end{array}$ & $\begin{array}{c}26 \\
41.9\end{array}$ & $\begin{array}{c}19 \\
30.6\end{array}$ \\
\hline $\begin{array}{l}\text { Terkadang, saya pikir } \\
\text { seluruh hidup saya akan } \\
\text { menjadi sengsara. }\end{array}$ & $\begin{array}{c}1 \\
1.6\end{array}$ & $\begin{array}{c}5 \\
8.1\end{array}$ & $\begin{array}{c}25 \\
40.3\end{array}$ & $\begin{array}{c}21 \\
33.9\end{array}$ & $\begin{array}{c}10 \\
16.1\end{array}$ \\
\hline $\begin{array}{l}\text { Terkadang, ada yang } \\
\text { mengeluh bahwa saya } \\
\text { memperlakukan mereka } \\
\text { dengan buruk. }\end{array}$ & $\begin{array}{c}1 \\
1.6\end{array}$ & $\begin{array}{c}2 \\
3.2\end{array}$ & $\begin{array}{c}22 \\
35.5\end{array}$ & $\begin{array}{c}26 \\
41.9\end{array}$ & $\begin{array}{c}11 \\
17.7\end{array}$ \\
\hline $\begin{array}{l}\text { Saya merasa sulit untuk } \\
\text { mengatasi saat segala } \\
\text { sesuatu berubah dalam hidup } \\
\text { saya. }\end{array}$ & $\begin{array}{c}1 \\
1.6\end{array}$ & $\begin{array}{c}10 \\
16.1\end{array}$ & $\begin{array}{c}25 \\
40.3\end{array}$ & $\begin{array}{c}21 \\
33.9\end{array}$ & $\begin{array}{c}5 \\
8.1\end{array}$ \\
\hline Saya bisa mengatasi stres. & $\begin{array}{l}0 \\
0\end{array}$ & $\begin{array}{l}0 \\
0\end{array}$ & $\begin{array}{c}18 \\
29.0\end{array}$ & $\begin{array}{c}25 \\
40.3\end{array}$ & $\begin{array}{c}19 \\
30.6 \\
\end{array}$ \\
\hline $\begin{array}{l}\text { Saya tidak tahu bagaimana } \\
\text { menunjukkan kepada orang- } \\
\text { orang yang dekat dengan } \\
\text { saya bahwa saya peduli } \\
\text { terhadap mereka. }\end{array}$ & $\begin{array}{c}2 \\
3.2\end{array}$ & $\begin{array}{c}7 \\
11.3\end{array}$ & $\begin{array}{c}28 \\
45.2\end{array}$ & $\begin{array}{c}23 \\
37.1\end{array}$ & $\begin{array}{c}2 \\
3.2\end{array}$ \\
\hline $\begin{array}{l}\text { Saya bisa "masuk ke dalam } \\
\text { sepatu seseorang" dan } \\
\text { merasakan emosinya. }\end{array}$ & $\begin{array}{l}0 \\
0\end{array}$ & $\begin{array}{c}7 \\
11.3\end{array}$ & $\begin{array}{c}20 \\
32.3\end{array}$ & $\begin{array}{c}25 \\
40.3\end{array}$ & $\begin{array}{c}10 \\
16.1\end{array}$ \\
\hline $\begin{array}{l}\text { Saya merasa sulit untuk } \\
\text { tetap termotivasi. }\end{array}$ & $\begin{array}{l}0 \\
0\end{array}$ & $\begin{array}{c}4 \\
6.5 \\
\end{array}$ & \begin{tabular}{|c|}
31 \\
50.0 \\
\end{tabular} & $\begin{array}{c}18 \\
29.0\end{array}$ & $\begin{array}{c}9 \\
9.5 \\
\end{array}$ \\
\hline $\begin{array}{l}\text { Saya bisa mengendalikan } \\
\text { kemarahan saya saat saya } \\
\text { mau. }\end{array}$ & $\begin{array}{l}0 \\
0\end{array}$ & $\begin{array}{l}0 \\
0\end{array}$ & $\begin{array}{c}16 \\
25.8\end{array}$ & $\begin{array}{c}29 \\
46.8\end{array}$ & $\begin{array}{c}17 \\
27.4\end{array}$ \\
\hline $\begin{array}{l}\text { Saya senang dengan hidup } \\
\text { saya. }\end{array}$ & $\begin{array}{l}0 \\
0\end{array}$ & $\begin{array}{l}0 \\
0\end{array}$ & $\begin{array}{c}6 \\
9.7 \\
9\end{array}$ & $\begin{array}{c}26 \\
41.9\end{array}$ & $\begin{array}{c}30 \\
48.4 \\
\end{array}$ \\
\hline $\begin{array}{l}\text { Saya akan menggambarkan } \\
\text { diri saya sebagai negosiator } \\
\text { yang baik. }\end{array}$ & $\begin{array}{l}0 \\
0\end{array}$ & $\begin{array}{l}0 \\
0\end{array}$ & $\begin{array}{c}24 \\
38.7\end{array}$ & $\begin{array}{c}28 \\
45.2\end{array}$ & $\begin{array}{c}10 \\
16.1\end{array}$ \\
\hline $\begin{array}{l}\text { Terkadang, saya terlibat } \\
\text { dalam hal-hal yang } \\
\text { kemudian saya harap bisa } \\
\text { saya dapatkan. }\end{array}$ & $\begin{array}{c}5 \\
8.1\end{array}$ & $\begin{array}{c}27 \\
43.5\end{array}$ & $\begin{array}{c}24 \\
38.7\end{array}$ & $\begin{array}{c}5 \\
8.1\end{array}$ & $\begin{array}{c}1 \\
1.6\end{array}$ \\
\hline $\begin{array}{l}\text { Saya menaruh banyak } \\
\text { perhatian pada perasaan } \\
\text { saya. }\end{array}$ & $\begin{array}{l}0 \\
0\end{array}$ & $\begin{array}{l}0 \\
0\end{array}$ & $\begin{array}{c}18 \\
29.0\end{array}$ & $\begin{array}{c}27 \\
43.5\end{array}$ & $\begin{array}{c}17 \\
27.4\end{array}$ \\
\hline $\begin{array}{l}\text { Saya merasa baik tentang } \\
\text { diri saya sendiri. }\end{array}$ & $\begin{array}{l}0 \\
0\end{array}$ & $\begin{array}{l}0 \\
0\end{array}$ & \begin{tabular}{|c|}
20 \\
32.3 \\
\end{tabular} & \begin{tabular}{|c|}
24 \\
38.7
\end{tabular} & $\begin{array}{c}18 \\
29.0\end{array}$ \\
\hline $\begin{array}{l}\text { Saya cenderung "mundur" } \\
\text { bahkan jika saya tahu saya } \\
\text { benar. }\end{array}$ & $\begin{array}{c}10 \\
16.1\end{array}$ & $\begin{array}{c}21 \\
33.9\end{array}$ & $\begin{array}{c}19 \\
30.6\end{array}$ & $\begin{array}{c}10 \\
16.1\end{array}$ & $\begin{array}{c}2 \\
3.2\end{array}$ \\
\hline $\begin{array}{l}\text { Saya tidak dapat mengubah } \\
\text { cara yang dirasakan orang } \\
\text { lain. }\end{array}$ & $\begin{array}{c}3 \\
4.8\end{array}$ & $\begin{array}{c}16 \\
25.8\end{array}$ & $\begin{array}{c}29 \\
46.8\end{array}$ & $\begin{array}{c}9 \\
14.5\end{array}$ & $\begin{array}{c}5 \\
8.1\end{array}$ \\
\hline $\begin{array}{l}\text { Saya percaya bahwa } \\
\text { semuanya akan berjalan baik } \\
\text { dalam hidup saya. }\end{array}$ & $\begin{array}{l}0 \\
0\end{array}$ & $\begin{array}{l}0 \\
0\end{array}$ & $\begin{array}{c}18 \\
29.0\end{array}$ & $\begin{array}{c}19 \\
30.6\end{array}$ & $\begin{array}{c}25 \\
40.3\end{array}$ \\
\hline $\begin{array}{l}\text { Terkadang, saya berharap } \\
\text { bisa memiliki hubungan } \\
\text { yang lebih baik dengan } \\
\text { orang tua saya. }\end{array}$ & $\begin{array}{c}43 \\
69.4\end{array}$ & $\begin{array}{c}16 \\
25.8\end{array}$ & $\begin{array}{c}3 \\
4.8\end{array}$ & $\begin{array}{l}0 \\
0\end{array}$ & $\begin{array}{l}0 \\
0\end{array}$ \\
\hline
\end{tabular}

\begin{tabular}{|c|c|c|c|c|c|}
\hline $\begin{array}{l}\text { Saya bisa mengatasi dengan } \\
\text { baik di lingkungan baru. }\end{array}$ & $\begin{array}{l}0 \\
0\end{array}$ & $\begin{array}{c}4 \\
6.5\end{array}$ & $\begin{array}{c}16 \\
25.8\end{array}$ & $\begin{array}{c}24 \\
38.7\end{array}$ & $\begin{array}{c}18 \\
29.0\end{array}$ \\
\hline $\begin{array}{l}\text { Saya mencoba } \\
\text { mengendalikan pikiran sava }\end{array}$ & 0 & 3 & 26 & 19 & 14 \\
\hline $\begin{array}{l}\text { dan tidak terlalu memikirkan } \\
\text { banyak hal. }\end{array}$ & 0 & 4.8 & 41.9 & 30.6 & 22.6 \\
\hline
\end{tabular}

Keterangan: angka atas (F) dan bawah (\%).

Tabel 2 menunjukkan bahwa deskripsi frekuensi dan persentase jumlah keseluruhan jawaban responden pada 30 pernyataan dalam kuesioner penelitian memiliki tren positif. Selanjutnya apabila dinilai sesuai kriteria tabel 1, maka dapat dijelaskan sebagai berikut: 1) Responden yang memiliki tingkat kecerdasan emosional yang sangat baik berjumlah 3 orang $(4,8 \%), 2)$ Responden yang tingkat kecerdasan emosional baik berjumlah 58 orang $(93,3 \%)$, dan 3) Responden yang tingkat kecerdasan emosional cukup berjumlah 1 orang $(1,6 \%)$. Sedangkan tidak ada responden yang memiliki kecerdasan emosional pada golongan kurang dan buruk (0\%). Dengan demikian disimpulkan bahwa mahasiswa Pendidikan Jasmani, Kesehatan, dan Rekreasi semester VII, kelas E/F di Universitas Kristen Artha Wacana Kupang memiliki kecerdasan emosional yang baik.

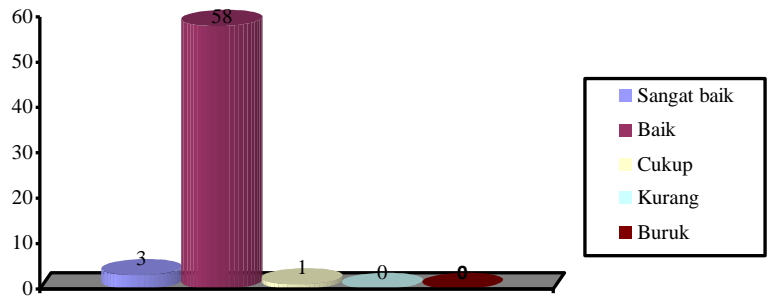

Gambar 1. Kecerdasan Emosional Responden

Kecerdasan emosional menyiratk an prediksi bagaimana mahasiswa dalam kecenderungan dalam bertindak atau bereaksi di bawah keadaan yang berbedabeda. Walaupun secara faktual, tidak ada yang sederhana dalam merespon situasi yang tidak dapat diprediksi sepenuhnya (Jaya, Mulyadi, \& Sulaeman, 2012). Namun secara keseluruhan, kecerdasan emosional responden tergolong baik (58 orang atau 93,3\%), sehingga dapat memotivasi dan memengaruhi perilaku belajar mahasiswa untuk mencapai tujuan (Blegur, 2017).

Gradasi kecerdasan emosional setiap mahasiswa berbeda satu dengan yang lain. Perbedaan tersebut dapat dilihat dari tanggapan mahasiswa dalam menyikapi setiap masalah belajar yang dihadapi. Tanggapantanggapan tersebut lebih pada pembedayaan proses berpikir dan betindak sehingga ia dapat selektif membuat keputusannya yang pada akhirnya berpengaruh terhadap prestasi belajar yang dicapai (Marhaeni, 2016). Mahasiwa tidak terlalu sibuk pada hal-hal yang menguras emosi dan pikirannya. Ia sadar bahwa hal demikian tidak produktif, mereka malah memikirkan hal yang berguna sehingga mahasiswa dengan kecerdasan emosional yang baik akan memiliki prestasi akademik 
(Mohzan, Hassan, \& Halil, 2013) yang baik serta sukses dalam bidang akademik (Farooq, Riaz, \& Javid, 2017).

Kecerdasan emosional adalah kemampuan untuk memahami dan mengekspresikan emosi untuk merangsang pemikiran, memahami, dan bernalar. Termasuk mengatur emosi dalam diri sendiri dan orang lain (Anand \& UdayaSuriyan, 2010). Kecerdasan emosional juga dapat ditunjukkan dengan bagaimana mahasiswa mudah untuk membicarakan perasaan dengan orang lain, sering melihat sesuatu dari sudut pandang orang lain, mahasiswa orang yang sangat termotivasi, mampu mengendalikan perasaan mereka, hidup mereka menyenangkan, pandai bergaul dengan teman kelas, maupun jarang berubah pikiran dalam artian menunjukan bahwa mahasiswa cenderung fokus dengan apa yang mereka jalani.

Selain itu, mahasiswa juga mampu mengetahui dengan pasti emosi yang mereka rasakan. Mereka juga merasakan kenyamanan dari setiap penampilannya di kelas. Mahasiswa mampu membela hak mereka jika itu adalah benar, mampu membuat orang menjadi lebih baik saat mereka mau, mahasiswa berpikir bahwa seluruh hidup mereka tidak menjadi sengsara, memperlakukan sesama mereka dengan baik, mampu mengatasi sesuatu yang berubah dalam hidup mereka, bisa mengatasi stres, mereka tahu menunjukan kepada orang lain bahwa mereka peduli dengan orang lain, mereka mampu merasakan emosi orang lain.

Kecerdasan emosional menyangkut banyak aspek diantaranya kemampuan berempati dalam memahami orang lain dan perasaan orang lain, memahami dan mengungkapkanperasaan serta penghayatan, mengontrol amarah, kemandirian, kemampuan adaptasi diri, disukai oleh orang lain, kemampuan pemecahan masalah interpersonal, ketekunan, kesetiakawanan dan keramahan, serta sikap respek berpengaruh terhadap keberhasilan proses belajar (Widodo, 2008). Dengan kecerdasan emosional yang baik pun mahasiswa mudah untuk tetap termotivasi, bisa mengendalikan kemarahan mereka saat mereka mau, mahasiswa senang dengan hidup mereka, mahasiswa akan menggambarkan diri mereka sebagai negosiator yang baik.

Mahasiswa dapat menaruh banyak perhatian pada perasaan mereka, sebab ada keyakinan pada kemampuan yang dimiliki sehingga berdampak positif dalam diri dan hidupnya. Mereka dapat mengubah cara yang dirasakan orang lain serta percaya bahwa semuanya akan berjalan baik dalam hidup mereka. Mereka bisa mengatasi dengan baik di lingkungan baru dan bisa mengendalikan pikiran mereka. Ini adalah poin penting yang membantu mahasiswa untuk berhasil dalam kehidupan baik dalam bidang pekerjaan, maupun kemasyarakatan. Karena menurut Widians \& Saputra (2017), keberhasilan seseorang banyak dipengaruhi oleh sikap dan sifat-sifat kepribadian. Kegagalan dapat saja terjadi karena sesorang kurang percaya diri. Pesimis atau hal yang lainnya yang mungkin kurang positif tanpa disadari atau bahkan tidak diketahui sama sekali oleh dirinya.
Mahasiswa yang memiliki tingkat kecerdasan emosional yang baik dapat menjadi lebih terampil dengan kecakapan yang dimiliki dalam menenangkan dirinya dengan cepat, jarang tertular penyakit, lebih terampil untuk fokus. Mereka akan lebih baik dalam berkomunikasi dengan orang lain, lebih cakap dalam memahami orang lain dan secara akademis di lingkungan pendidikan akan menjadi lebih baik dalam aktualisasi kinerjanya. Hal-hal demikian juga menunjukkan bahwa mahasiswa memiliki faktor internal yang kuat dalam meningkatkan kinerja akademiknya. Sebab faktor internal yang dapat mempengaruhi kinerja akademik seseorang adalah kecerdasan, motivasi, dan kepribadian (Mulyati \& Setiani, 2018).

Mahasiswa dengan kecerdasan emosional rendah lebih menunjukan bahwa mereka acap kali terlibat dalam hal-hal yang mereka harap bisa mereka dapatakan. Namum meraka sulit atau bahkan tidak bisa mendapatkan hal-hal yang mereka harapkan tersebut karena suasana hati yang buruk. Selain itu, mereka cenderung mundur bahkan mereka tahu bahwa mereka benar dari setiap tindakannya. Kesulitan mereka juga karena hubungan horizontal yang kurang harmonis sehingga menimbulkan keengganan satu sama lainnya. Alhasil mereka belum realistik dalam bertindak.

Kemampuan mahasiswa dalam mengelola kemampuan emosi yang rendah dan kurang baik akan dapat menimbulkan kerugian intrapersonal mahasiswa itu sendiri, karena kemampuan pengontrolan emosi memiliki dampak untuk keberhasilan mahasiswa dalam merespon pembelajaran. Dengan demikian mahasiswa tersebut dapat mencapai hasil belajar yang diinginkan (Anggara \& Kartiko, 2013). Mereka memilki kemampuan untuk secara efektif memahami, mengekspresikan, memahami, dan mengelola emosi dan emosi orang lain secara positif dan produktif (Anand \& UdayaSuriyan, 2010).

Individu yang memiliki kecerdasan emosional dengan pengembangan yang baik maka kemungkinan besar mereka kan bahagia dan berhasil dalam kehidupannya. Mereka juga dapat menguasai kebiasaan berpikir yang mendorong produktivitas individu (Erindra \& Qurniyawati, 2010). Kesuksesan mahasiswa yang ideal meliputi segenap ranah psikologi yang berubah sebagai akibat pengalaman dari proses belajarnya. Perkembangan pengetahuan serta emosi mahasiswa juga dipengaruhi oleh partisipasi secara fisik, mental, dan emosional dengan lingkungan dimana mahasiswa berada (Dewi, Kristiantari, \& Negara, 2014). Salah satu faktor yang ikut menentukan keberhasilan dalam belajar adalah kecerdasan emosional.

Faktor-faktor yang mempengaruhi kecerdasan emosional yaitu faktor lingkungan keluarga dan lingkungan non keluarga (Komalasari, 2012). Dalam proses pembelajaran, perubahan positif dalam aspekaspek intelektual, emosional atau sikap (keterampilan) yang dapat mempengaruhi kesuksesan mahasiswa. Ini melandas pada tanggapan yang diberikan oleh 
mahasiswa terhadap rangsangan (stimulus) yang timbul dari dalam diri maupun dari lingkungan ekstrinsik (Maisaroh \& Rostrieningsih, 2010).

Kecerdasan emosional berkaitan dengan kesempurnaan akal budi, ketajaman berpikir, serta kemampuan penyelesaian masalah dengan efektif dan mampu untuk mengendalikan diri. Mahasiswa dengan kecerdasan emosional mampu menyesuaikan diri dengan baik, mampu menghadapi kesukaran dengan cara yang objektif serta dapat menikmati kehidupannya dengan stabil, tenang, merasa senang. Mereka tertarik untuk belajar, bekerja dan berprestasi, mampu memotivasi diri terhadap kritik dan tuntutan kehidupan, tidak melebihlebihkan kesenangan atau kesusahan sehingga mereka dapat mengelola kehidupannya yang banyak dipengaruhi emosi (Hidayati, Purwanto, \& Yuwono, 2008).

\section{KESIMPULAN}

Kecerdasan emosional dari potret penelitian ini menunjukkan hasil yang positif $(93,3 \%)$. Perilaku yang paling dominan dalam respon responden ialah mereka menganggap bahwa diriny mudah bergaul dengan orang sekelasnya. Mereka juga nyaman dengan setiap performa yang mereka tampilkan, serta merasa senang dengan kehidupan yang mereka jalani sekarang. Kecerdasan emosional juga ditandai dengan responden percaya bahwa kehidupannya akan berlangsung dengan baik sehingga sampai dengan saat ini (pengisian kuesioner), belum ada hal yang ia khawatirkan.

Aktivitas pembelajaran mahasiswa yang santai dan "luwes" membantu mereka mengontruksikan perasaan dan pikiran yang lebih aktif. Misalnya saja tidak ada keengganan diantara sesama mahasiswa untuk saling bertanya dan saling membantu. Selain itu, mereka tidak merasa "terancam" dengan tugas-tugas akademik yang diberikan oleh dosen. Perilaku belajar mahasiswa yang belajar dalam keadaan emosional yang stabil dan metastabil tentu berbeda, salah satunya ialah bagaimana mereka merespon tugas belajarnya. Mereka bahkan menanggapi dengan santai, karena mereka merasa bahwa tugas adalah cara mereka melatih kapasitas diri.

\section{SARAN}

Potret kematangan emosional mahasiswa saat ini masih cenderung fluktuatif untuk rentang usia remaja. Masih dijumpai mahasiswa yang melewati pengalaman hidup dengan "bergantung" pada kondisi eksternal. Aplikasi atmosfir pembelajaran yang suportif dan reorientasi dari penilaian kepada perbaikan atau evaluasi amatlah penting agar menfasilitasi mahasiswa untuk terus tumbuh dalam semangat belajar yang bergairah dan solutif. Rekayasa sosial melalui pembelajaran diperlukan agar memantapkan kecerdasan emosional positif mereka menjadi sebuah karakter hidup.

Penelitian untuk membandingkan kecerdasan emosional berdasarkan metode mengajar, kompetensi dosen, serta hasil belajar perlu dikaji guna memberikan kesimpulan yang lebih komprehensif tentang kontribusi kecerdasan emosional mahasiswa. Selain itu, pecahanpecahan dari atribut kecerdasan emosional juga perlu ditelisik sehingga memberi informasi yang lebih detail dari artribut kecerdasan emosional manakah yang paling dibutuhkan mahasiswa untuk menunjang masa depan karir akademik dan karir kerjanya.

\section{DAFTAR PUSTAKA}

Anand, R., \& UdayaSuriyan, G. 2010. Emotional Intelligence and its Relatinship with Leadership Practice. International Journal of Business and Management, 5(2), 65-76.

Andriani, A. 2014. Kecerdasan Emosional (Emotional Quotient) dalam Peningkatan Prestasi Belajar. Edukasi, 2(1), 459-472.

Anggara, D. S. \& Kartiko, D. C. (2013). Hubungan Kecerdasan Emosional Terhadap Hasil Belajar LayUp Bola Basket: Studi Pada Siswa Kelas XI IPA 5 SMA Negeri 2 Nganjuk. Jurnal Pendidikan Olahraga dan Kesehatan, 1(1), 41-45. Retrieved from:

http://jurnalmahasiswa.unesa.ac.id/index.php/jurnal -pendidikan-jasmani/article/view/2792

Blegur, J. \& Wasak, M. R. P. 2017. Permainan Kecil: Teori dan Aplikasi. Kupang: Jusuf Aryani Learning.

Blegur, J. 2017. Eksplorasi Motivasi Belajar Peserta Didik dengan Mediasi Metode Mengajar. Seminar Hasil Penelitian Pendidikan Pemberdayaan Hasil Penelitian melalui Seminar (hal. 140-150), 21 Januari, Jakarta, Indonesia.

Blegur, J., Wasak, M. R. P., \& Pabala, P. 2018. Students' Academic Self-Concept: A Founding Strategy in Learning Process. International Journal of Indian Psychology, 6(4), 44-54. https://ijip.in/articledetails/?dip=18-01-046-20180604

Daud, F. 2012. Pengaruh Kecerdasan Emosional (EQ) dan Motivasi Belajar terhadap Hasil Belajar Biologi Siswa SMA 3 Negeri Kota. Jurnal Pendidikan dan Pembelajaran, 19(2), 243-255. Retrieved from: http://journal.um.ac.id/index.php/pendidikan-danpembelajaran/article/view/3475

Dewi, N. W. B. S., Kristiantari, M. G. R., \& Negara, I. G. A. O. 2014. Model Tematik Bernuansa Kearifan Lokal Berbantuan Media Animasi Berpengaruh terhadap Hasil Belajar IPA Siswa Kelas III SD Negeri Gugus Kapten Japa. Jurnal Mimbar PGSD, 2(1). 1-10. Retrieved from: https://ejournal.undiksha.ac.id/index.php/JJPGSD/a rticle/view/3065

Ely, M. H. 2016. Mengelola Kecerdasan Emosi. Tadrib: Jurnal Pendidikan Agama Islam, 2(2), 1-16. http://jurnal.radenfatah.ac.id/index.php/Tadrib/articl e/view/1168

Erindra, B. C. \& Qurniyawati, E. 2010. Hubungan Kecerdasan Emosional dengan Prestasi Belajar Pada Mahasiswa Program Studi D IV Kebidanan FK UNS. Wacana: Jurnal Psikologi, 2(2), 1-15. 
http://jurnalwacana.psikologi.fk.uns.ac.id/index.php /wacana/article/view/49/49

Eva, L., \& Kusrini, M. 2015. Hubungan Kercerdasan Emosional dan Berpikir Kreatif terhadap Prestasi Belajar Matematik, Formatif: Jurnal Ilmiah Pendidikan MIPA, 5(3), 245-256. DOI: 10.30998/formatif.v5i3.650

Farooq, M. U., Riaz, K., \& Javid, C. Z. 2017. Impact of Emotional Intelligence on Academic Achievement of English Language Learners. Journal of Social Sciences and Humanities, 25(2), 1-33.

Fatchurahman, M., \& Pratikto, H. 2012. percayaan Diri, Kematangan Emosi, Pola Asuh Orang Tua Demokratis dan Kenakalan Remaja. Persona: Jurnal Psikologi Indonesia, 1(2), 77-87. DOI: https://doi.org/10.30996/persona.v1i2.27

Gitosarono, M. 2012. Kecerdasan Emosi (Emotional Intelligence) dalam Tasawuf. Jurnal Khatulistiwa, 2(2), 182-200. DOI: https://doi.org/10.24260/khatulistiwa.v2i2.206

Gusniwati, M. 2015. Pengaruh Kecerdasan Emosional dan Minat Belajar terhadap Penguasaan Konsep Matematika Siswa SMAN di Kecamatan Kebon Jeruk. Jurnal Formatif, 5(1), 26-41. DOI: http://dx.doi.org/10.30998/formatif.v5i1.165

Guswani, A. M. 2011. Perilaku Agresi Pada Mahasiswa Ditinjau Dari Kematangan Emosi. Jurnal Psikologi Pitutur, 1(2), 86-92.

Hamalik, O. 2009. Proses Belajar Mengajar. Jakarta: Bumi Aksara.

Hidayati, R., Purwanto, Y., \& Yuwono, S. 2008. Kecerdasan Emosional, Stres Kerja dan Kinerja Karyawan. Jurnal Ilmiah Psikologi, 2(1), 91-95. Retrieved from: https://ejournal.gunadarma.ac.id/index.php/psiko/ar ticle/view/249

Husdarta, H. J. S. 2015. Manajemen Pendidikan Jasmani. Bandung: Alfabeta.

Jaya, M. K., Mulyadi, D., \& Sulaeman, E. 2012. Pengaruh Kecerdasan Emosional terhadap Kinerja Karyawan Pada Kantor Kementerian Agama Kabupaten Karawang. Jurnal Manajemen. 10(1), 1038-1046.

Komalasari, O. 2012. Hubungan antara Kecerdasan Emosional terhadap Prestasi Belajar Seni Budaya. Skripsi, Universitas Muhammadiyah Surakarta. Retrieved from: http://eprints.ums.ac.id/20319/

Labhane, C. P., \& Baviskar, P. A. 2015. Self Concept and Emotional Intelligence: A Comparative Study of Arts and Science College Students. The International Journal of Indian Psychology, 2(2), 84-90.

Magnano, P., Craparo, G., \& Paolillo, A. 2016. Resilience and Emotional Intelligence: Which Role in Achievement Motivation. International Journal of Psychological Research, 9(1), 9-20. https://doi.org/10.21500/20112084.2096
Maisaroh \& Rostrieningsih. 2010. Peningkatan Hasil Belajar Siswa dengan Menggunakan Metode Pembelajaran Active Learning Tipe Qius Team Pada Mata Pelajaran Keterampilan Dasar Komunikasi di SMK Negeri 1 Bogor. Jurnal Ekonomi dan Pendidikan, 7(2), 157-172. DOI: https://doi.org/10.21831/jep.v7i2.571

Marhaeni, N. 2016. Hubungan Kecerdasan Emosi dengan Prestasi Belajar Matematika Siswa Kelas V Sekolah Dasar I Kecamatan Wates Kabupaten Kulon Progo tahun ajaran 2015/2016. Jurnal Pendidikan Guru Sekolah Dasar, 5(4), 334-343. Retrieved from: http://journal.student.uny.ac.id/ojs/index.php/pgsd/a rticle/view/955

Mohzan, M. A. M., Hassan, N., \& Halil, N. A. 2013. The Influence of Emotional Intelligence on Academic Achievement. Procedia-Social and Behavioral Science, 90(10), 303-312. https://doi.org/10.1016/j.sbspro.2013.07.095

Mulyati, S., \& Setiani, N. 2018. Indentifying Students' Academic Achievement and Personality Types with Naive Bayes Classification. Sebatik, 22(2), 64-68. Retrieved from: http://jurnal.wicida.ac.id/index.php/sebatik/article/v iew/309

Nwadinigwe, I. P. \& Azuka-Obieke, U. 2012. The Impact of Emotional Intelligence on Academic Achievement of Senior Secondary School Students in Lagos, Nigeria. Journal of Emerging Trends in Educational Research and Policy Studies, 3(4), 395-401. Retrived from: https://hdl.handle.net/10520/EJC126563

Paramitasari, R., \& Alfian, I. N. 2012. Hubungan antara Kematangan Emosi dengan Kecenderungan Memaafkan Pada Remaja Akhir. Jurnal Psikologi Pendidikan dan Perkembangan, 1(2), 1-7.

Petrides, K. V., Sangereau, Y., Furnham, A., \& Frederickson, N. 2006. Trait Emotional Intelligence and Children's Peer Relation at School. Social Development, $\quad$ 15, 537-547. https://doi.org/10.1111/j.1467-9507.2006.00355.x

Putri, M. P., Asrori, M., \& Astuti, I. 2015. Korelasi Kecerdasan Emosional dengan Interaksi Sosial Siswa Kelas VII MTs Negeri 2 Pontianak. Jurnal Pendidikan dan Pembelajaran, 4(9), 1-13.

Rahman, A., Sulistiawati, \& Arifin, S. 2018. Hubungan antara Kecerdasan Emosional dan Motivasi Belajar dengan Prestasi Belajar Matematika Siswa SMP. Teorema, 3(2), 165-176. DOI: http://dx.doi.org/10.25157/teorema.v3i2.1557

Setyowati, A., Hartati, S., \& Sawitri, D. R. 2010. Hubungan antara Kecerdasan Emosional dengan Resiliensi Pada Siswa Penghuni Rumah Damai. Jurnal Psikologi, 7(1), 67-77. DOI: https://doi.org/10.14710/jpu.7.1.67-77 
Sumiyarsih, W., Mujiasih, E., \& Ariati, J. 2012. Hubungan antara Kecerdasan Emosional dengan Organizational Citizenship Behavorial (OCB) Pada Karyawan CV. Aneka Ilmu Semarang. Jurnal Psikologi, 11(1), 19-27. DOI: https://doi.org/10.14710/jpu.11.1.9

Thaib, Eva Nauli. 2013. Hubungan antara Prestasi Belajar dengan Kecerdasan Emosional. Jurnal Ilmiah Didakti, 13(2), 384-399.

Widians, J. A., \& Saputra, I. A. 2017. Aplikasi Sistem Pakar Skoring Tes IQ menggunakan Alat CFIT. Sebatik, 17(1), 1-5. Retrieved from: http://www.jurnal.wicida.ac.id/index.php/sebatik/ar ticle/view/78

Widodo \& Widayanti, L. 2013. Peningkatan Aktivitas Belajar dan Hasil Belajar Siswa dengan Metode Problem Based Learning Pada Siswa Kelas VII A MTs Negeri Donomulyo Kulon Progo Tahun Pelajaran 2012/2013. Jurnal Fisika Indonesia, 17(49), 32-35.
Widodo, B. S. 2008. Pentingnya Kecerdasan Emosional dalam Pendidikan. http:/bambangsw.blogspot.com/2008/05/pentingnya-eq.html.

Wulandari, D. 2012. Gambaran Kecerdasan Emosional Pada Siswa SMKN 1 Jakarta. Jurnal Penelitian dan Pengukuran Psikologi, 1(1), 183-190.

Yakub, S., Gunawan, R., \& Halim, J. 2015. Pengaruh Kemampuan Komunikasi dan Kecerdasan Emosional terhadap Kinerja Karyawan Pada PT. Perkebunan Nusantara I (Persero)Aceh. Jurnal SAINTIKOM, 14(3), 160-170.

\section{UCAPAN TERIMA KASIH}

Terima kasih disampaikan kepada Tim Pengabdian Universitas Kristen Artha Wacana yang telah mendukung memfasilitasi kegiatan Pelatihan Penulisan Karya Ilmiah Mahasiswa pada bulan September tahun 2017 sehingga penelitian dan naskah ini dapat terselesaikan dengan baik 